\title{
СУТНІСТЬ ПРИНЦИПІВ КОНФЛІКТУ ЗАКОНІВ У СФЕРІ ІНТЕЛЕКТУАЛЬНОЇ ВЛАСНОСТІ
}

Вступ. Принципи CLIP (Principles on Conflict of Laws in Intellectual Property) являють собою звід альтернативних доктринальних правил колізійного регулювання відносин інтелектуальної власності в Європейському Союзі (далі - ЄС), метою яких є уніфікація колізійних норм, що стосуються специфічних відносин інтелектуальної власності, для врегулювання нормативних прогалин та неефективних підходів у регламентах $€ \mathrm{C}$ у цій сфері. У вітчизняній наукові літературі не приділено належної уваги змісту, характеристиці та значенню цих принципів для колізійного регулювання відносин інтелектуальної власності.

Постановка завдання. У статті авторка розкриває структуру та зміст «Принципів конфлікту законів у сфері інтелектуальної власності» (далі - Принципи CLIP) (Principles on Conflict of Laws in Intellectual Property), ї значення в регулюванні колізійних відносин інтелектуальної власності в Європейському Союзі. Дані принципи являють собою звід альтернативних доктринальних правил колізійного регулювання інтелектуальної власності в Європейському Союзі, метою яких є уніфікація колізійних норм, що стосуються специфічних відносин інтелектуальної власності, для врегулювання нормативних прогалин та неефективних підходів у регламентах $Є С$ у цій сфері.

Результати дослідження. На рівні Європейського Союзу відносини інтелектуальної власності колізійно врегулювано в:

1. Регламенті (ЄС) № 2015/2012 Європейського парламенту та Ради від 22 грудня 2015 р. «Про юрисдикцію, визнання та виконання судових рішень у цивільних та комерційних справах" (відомий як Регламент «Брюссель I bis") - щодо визначення юрисдикції у спорах, що стосуються інтелектуальної власності

2. Регламенті (ЄС) № 864/2007 Європейського парламенту та Ради «Щодо права, яке підлягає застосуванню до позадоговірних зобов'язань (відомий як «Рим II»)» - щодо визначення права, що підлягає застосуванню до позадоговірних (недоговірних) відносин.

3. Регламенті (ЄС) № 593/2008 Європейського парламенту та Ради «Про право, яке підлягає застосуванню щодо договірних зобов'язань» від 17 червня 2008 p. (відомий як «Рим I») - щодо визначення права, що підлягає застосуванню до договірних відносин.

Положення вищезазначених реґламентів ЄС у закордонних наукових колах викликають критику. Підстави для цієї критики в узагальненому сенсі зводяться до неефективності та непрактичності застосування визначених регламентами підходів під час вибору права, що підлягає застосуванню, та встановленню юрисдикції 
у спорах з інтелектуальної власності, з огляду на особливий статус, «специфічність» об'єктів інтелектуальної власності; відсутність правової регламентації з вирішення спорів з інтелектуальної власності в мережі Інтернет.

3 огляду на це виникає потреба в уточненні, доопрацюванні, внесенні змін у наявні регламенти або ухвалення нових документів, спеціальним предметом яких було б виключне регулювання колізійних відносин інтелектуальної власності на просторах Європейського Союзу, що, на наш погляд, є більше доречним.

Так, саме із цією метою група науковців у сфері інтелектуальної власності та міжнародного приватного права, що об’єднались і створили Європейську групу Макса Планка з конфлікту законів в інтелектуальній власності, підготували «Принципи конфлікту законів у сфері інтелектуальної власності» (в остаточній редакції від 1 грудня 2011 р.). Принципи CLIP є уніфікованим зводом правил регулювання колізійних відносин інтелектуальної власності.

Принципи CLIP, хоча і спрямовані на міжнародний рівень, усе ж у своїй основі мають «корені» європейського правового мислення. I група Макса Планка передусім у своїх пропозиціях спиралася на чинне європейське законодавство, а саме регламенти «Рим I», «Рим II», «Брюссель I bis”.

Варто зазначити, що в наукових публікаціях вітчизняних учених, що стосуються питання юрисдикції, та застосованого права в міжнародних приватних спорах інтелектуальної власності не приділено уваги Принципам CLIP. У працях закордонних учених активно висвітлюються положення Принципів CLIP, у наукових публікаціях, що стосуються дослідження транскордонної юрисдикції та права, що підлягає застосуванню у спорах, пов'язаних з інтелектуальною власністю.

Принципи CLIP досліджувались та коментувались у наукових працях таких учених, як: Педро де Мігель Асенсіо [7], Аксель Мецгер [6], Аннет Кур [5] та Пол Торреманс, Томас Драйє [8] та інші.

Авторами Принципів CLIP є провідні європейські вчені з різних країн, обізнані у специфіці відносин інтелектуальної власності, які на грунті доктринальних знань, ураховуючи специфічність відносин інтелектуальної власності й аспекти ефективного практичного застосування норм, створили дані правила. Це Юрген Баседоу (J rgen Basedow) - учений-юрист, директор Інституту порівняльного та міжнародного приватного права Макса Планка в Гамбурзі та професор Гамбурзького університету, Грейм Дінвуді (Graeme Dinwoodie), професор права інтелектуальної власності в юридичному коледжі Чикаго-Кент, професор права інтелектуальної власності та інформаційних технологій в Оксфордському університеті (2009-2918рр.), Йозеф Дрексл (Josef Drexl), доктор юридичних наук, почесний професор Мюнхенського університету, інші визначні вчені сучасності.

У 2013 p. Oxford University Press видало єдиний коментар до Принципів CLIP, написаний авторами самих Принципів CLIP, які містять коментарі до статей та примітки, що аналізують контекст правил Принципів. Коментар деталізує політичні міркування, що лежать в їх основі, щоб краще зрозуміти, чому пропонуються саме такі рішення та колізійні підходи, а не інакші. 
За структурою Принципи CLIP складаються із Преамбули та чотирьох розділів:

1. Цілі та сфера застосування.

2. Юрисдикція.

3. Застосовне право.

4. Визнання та примусове виконання рішень.

Аннет Кур, співавторка Принципів CLIP, висвітлює в історичній ретроспективі мету та шлях створення документа. Так, довгий час питання транскордонної юрисдикції та застосовного права не були вирішені на рівні міжнародної гармонізації, фактично просувалась лише гармонізація матеріального законодавства про інтелектуальну власність. 31999 р. почали формуватися академічні ініціативи у Сполучених Штатах Америки, Азії (Японія та Корея), Європі з метою продовження досліджень можливих способів розроблення правил, що застосовуються у транскордонних конфліктах, пов'язаних із правами інтелектуальної власності.

У результаті співпраці науковців світ побачили регіональні зводи правил регулювання транскордонних спорів з інтелектуальної власності, зокрема: Принципи Американського юридичного інституту (Принципи ALI), Принципи Європейської групи Макса Планка щодо конфлікту законів у сфері інтелектуальної власності (Принципи CLIP), Японська пропозиція «Прозорість», Принципи Корейської асоціації міжнародного приватного права (KOPILA), спільна пропозиція, розроблена членами Міжнародної асоціації міжнародного права Кореї й університету Васеди Японії тощо.

Однак звернемо увагу на основні положення Принципів CLIP, які відрізняються від норм регламентів ЄС у цій сфері.

1. Як відомо, основним підходом, що застосовується до колізійних позадоговірних відносин у сфері інтелектуальної власності СС, проголошеним у ст. 8 (1) Регламенту «Рим II», є принцип lex loci protectionis (право країни, стосовно якої ставиться вимога про захист). Ст. 8 (3) даного Регламенту заборонено застосування принципу lex voluntatis (автономії волі сторін) до колізійних позадоговірних відносин інтелектуальної власності [5, с. 203-204].

На наш погляд, основними новаторськими підходами Принципів CLIP, на відміну від норм Регламенту «Рим II» (хоча загалом дотримано традиційний підхід, а саме застосування принципу lex loci protectionis (ст. 3:102)), є дозвіл за необхідності та доцільності, залежно від обставин справи відійти від суворого дотримання цього принципу. Тобто принцип lex loci protectionis не є беззаперечним підходом, який має застосовуватись до транскордонних спорів інтелектуальної власності в разі вибору права, що підлягає застосуванню [4].

Крім того, у ст. 3:101 Принципів CLIP установлено положення, яким дозволяється застосування закону суду (lex fori) до процесуальних питань [4].

Найпрогресивнішим положенням Принципів CLIP, на нашу думку, є те, що сторони можуть обрати закон, застосовний до їхнього спору (ст. 3:103) [4]. Тобто сторони вільні скористатися принципом автономії волі сторін lex voluntatis навіть у позадоговірних зобов'язаннях інтелектуальної власності.

Як відомо, відповідно до ст. 8 (3) Регламенту «Рим II», заборонено застосування принципу автономії волі сторін lex voluntatis навіть у позадоговірних зобов'язаннях інтелектуальної власності [1]. 
Європейські дослідники вважають заборону принципу автономії волі сторін lex voluntatis застарілим, необгрунтованим, таким, що не відповідає сучасності.

2. Також одним із нарікань на юрисдикційні правила з визначення компетентного суду, відповідно до Регламенту «Брюссель I bis”, є те, що ним не врегульовуються питання множинності відповідачів. Доведення «тісної пов'язаності вимог» через відсутність конкретизації у ст. 8 (1) Регламенту «Брюссель I bis” є практично незручним та неефективним [3].

Натомість Принципи CLIP виокремлюють ст. 2:206 «Підсудність за множинністю відповідачів». Як і в Регламенті «Брюссель I bis”, у Принципах CLIP взято за основу концепцію «тісної пов'язаності вимог», водночас деталізовано та конкретизовано критерії «взаємопов'язаності / або тісного зв'язку вимог» .

Так, у ст. 2:206 (1) Принципів CLIP передбачено, що особа, яка є одним зі співвідповідачів, може бути притягнута до відповідальності в суді держави, за місцем проживання будь-кого з інших співвідповідачів за умови, що позовні вимоги настільки тісно пов'язані, що їх доцільно слухати разом із метою уникнення ризику несумісні судових рішень, що виникають у результаті окремих проваджень [4].

Конкретизується у п. 2 цієї статті, що ризик невідповідних судових рішень полягає в ризику розбіжності в результаті дій щодо різних підсудних, що виникає в контексті по суті однакової ситуації за законом та за фактом ("the same situation of law and fact”): а) так, якщо з урахуванням індивідуальних обставин справи, спори включають по суті однакову фактичну ситуацію, навіть якщо відповідачі в різних державах діяли однаково чи аналогічно, відповідно до загальної політики; б) спори можуть мати по суті однакову правову ситуацію, навіть якщо до вимог проти різних відповідачів застосовуються різні національні закони, за умови, що відповідні національні закони значною мірою гармонізовані із правилами регіональної організації економічної інтеграції або міжнародними конвенціями, що застосовуються до спірних питань [4].

У ст. 2:206 (3) встановлено, якщо з фактів справи очевидно, що один відповідач координував відповідну діяльність інших співвідповідачів або іншим чином найбільш тісно пов'язаний зі спором у загальному обсязі, юрисдикція, згідно 3 п. 1, надається лише судам у державі, резидентом якої є цей відповідач. За винятком тих ситуацій, коли внесок такого відповідача є несуттєвим щодо спору загалом або позов проти відповідача-резидента явно неприпустимий [4].

3. Абсолютно кореспондують умовам сучасності правила Принципів CLIP, спрямовані на вирішення юрисдикційних питань у спорах інтелектуальної власності, пов'язаних із мережею Інтернет та засобами масової інформації (далі - 3MI). Регламент «Брюссель I bis” не передбачає взагалі жодних положень, застосовних до спорів у мережі Інтернет.

Так, у ст. 2:303 Принципів CLIP передбачено, що у спорах, пов’язаних з «усюдисущими 3МI», як-от Інтернет, суд, юрисдикція якого грунтується на ст. 2:202 (за місцем скоєння правопорушення), також має юрисдикцію стосовно порушень, які трапились або можуть статися на території будь-якої іншої держави, за умови, що діяльність, що спричиняє порушення, не має істотного ефекту в державі, де порушник має своє звичайне місце проживання, а істотні дії порушника, які сприяли 
порушенню, проводились саме на території держави, де знаходиться суд, або шкода, завдана даним порушенням у державі, де знаходиться суд, є більш істотною [4].

4. Також у розд. "Спеціальна юрисдикція» Принципи CLIP, окрім уже зазначених нами норм, що стосуються юрисдикції за множинності відповідачів і юрисдикції у спорах, пов'язаних із мережею Інтернет - які фактично неврегульовані в Регламенті «Брюссель I bis”, містяться статті, що стосуються юрисдикції цивільних позовів у рамках кримінального провадження - визначається як суд, що розглядає дане кримінальне провадження (2:204), та спорів, що стосуються права власності (entitlement and ownership) на права інтелектуальної власності, - це суди держави, де це право існує або щодо якого розглядається заява.

П.А. де Мігель Асенсіо розмірковує над роллю Принципів CLIP у Європі та відзначив, що в них є великі шанси вплинути на майбутній розвиток європейського міжнародного приватного права, у зв'язку із тим, що буде змінюватися чинна законодавча база ЄС. Водночас одне з основних питань, чи можна за наявності чинного режиму Регламенту СC «Рим II» застосовувати положення Принципів CLIP, що стосуються порушень у мережі Інтернет як “praeter legem"1, оскільки очевидно, що Регламент «Рим II» не є прийнятним і не дає вичерпних конкретних підходів щодо порушення прав інтелектуальної власності в Інтернеті [7, с. 52].

Висновки. Уважаємо, що загалом Принципи CLIP декларують традиційні концепції, що застосовуються у сфері міжнародного приватного права й інтелектуальної власності, - принци територіальності та lex loci protectionis. Однак, на противагу чинному європейському законодавству, Принципи CLIP максимально поважають принцип автономії волі сторін (там, де це не суперечить самій концепції права інтелектуальної власності). Крім того, Принципи CLIP дозволяють відійти від суворого застосування правил lex loci protectionis тоді, коли беззаперечне застосування цього принципу призвело б до перешкоджання правосуддю.

Ми вважаємо, що Принципи CLIP більше деталізовані ефективні правила колізійного регулювання відносин інтелектуальної власності, які охоплюють в «єдине ціле» правила договірної та позадоговірної відповідальності, а також правила визначення юрисдикцій у транскордонних IP-спорах, принаймні з нижченаведених підстав.

По-перше, Принципи CLIP є першою і єдиною натепер спеціальною уніфікацією правил, що стосуються конкретно відносин інтелектуальної власності на рівні Європейського Союзу, це звід правил щодо виключно законів інтелектуальної власності, зібраних у єдиному документі. По-друге, це звід альтернативних доктринальних правил колізійного регулювання інтелектуальної власності для Європейського Союзу, які створені на противагу законодавчим Регламентам ЄС у даній сфері. Авторами даних принципів є провідні європейській вчені різних країн, обізнані у специфіці відносин інтелектуальної власності, які на підставі грунтовних доктринальних знань, з урахуванням специфічності відносин інтелектуальної власності й аспектів ефективного практичного застосування норм, створили дані правила.

\footnotetext{
${ }^{1}$ Praeter legem (з лат. - «поза законом») - предмет, який не врегульований законом, тому не є незаконним. До предметів, які зазвичай позначаються praeter legem, належать певні звичаї (визначення з Вікіпедіі).
} 
Принципи CLIP містять важливі статті, що стосуються множинності відповідачів в IP-спорах, та вперше намагаються надати правове регулювання конфліктів, що стосуються IP-спорів у мережі Інтернет.

Ми вважаємо, що вивчення Принципів CLIP несправедливо залишили поза увагою вітчизняні дослідники, дані принципи можуть розглядатися як джерело для створення нового необхідного законодавчого нормативно-правового акта на рівні $Є С$ щодо колізійного регулювання відносин інтелектуальної власності.

\section{Jimepamypa}

1. Щодо права, яке підлягає застосуванню до позадоговірних зобов'язань : Регламент (ЄС) № 864/2007 Європейського парламенту та Ради (відомий як «Рим II»).

2. Про право, яке підлягає до застосування щодо договірних зобов'язань від 17 червня 2008 р. : Регламент (СС) № 593/2008 Європейського парламенту та Ради (відомий як «Рим I»).

3. Regulation (EU) No 1215/2012 of the European Parliament and of the Council of 12 December 2012 on jurisdiction and the recognition and enforcement of judgments in civil and commercial matters. URL: https://eur-lex.europa.eu/legal-content/EN/ALL/?uri=celex\%3A32012R1215 (дата звернення: 23.08.2019).

4. Principles on Conflict of Laws in Intellectual Property. Prepared by the European Max Planck Group on Conflict of Laws in Intellectual Property (CLIP) Final Text 1 December 2011. URL: https://www.ip.mpg.de/ fileadmin/ipmpg/content/clip/Final_Text_1_December_2011.pdf (дата звернення: 06.05.2020).

5. Annette Kur. The CLIP Principles - summary of the Project. URL: http://www.win-cls.sakura.ne.jp/ pdf/29/22.pdf (дата звернення: 06.05.2020).

6. Axel Metzger. Applicable law under the CLIP Principles: a pragmatic revaluation of territoriality. URL: https://www.rewi.hu-berlin.de/de/lf/ls/mzg/pub/applicable-law-under-the-clip-principles (дата звернення: 09.06.2020).

7. Asensio Miguel de Alberto Pedro. Recognition and enforcement of judgments in intellectual property litigation: the CLIP principles. URL: https://eprints.ucm.es/15214/1/Recognition-TokyoPDeMiguelf.pdf (дата звернення: 06.05.2020).

8. Kur Annette, Dreier Thomas. European Intellectual Property Law. Text, Cases and materials. Published by Edward Elgar Publishing Limited, 2013. 592 p.

\section{Анотація}

Лукань М. О. Сутність принципів конфлікту законів у сфері інтелектуальної власності. - Стаття.

У статті автор розкриває структуру та зміст «Принципів конфлікту законів у сфері інтелектуальної власності» (Принципи CLIP), їх значення в регулюванні конфліктних відносин інтелектуальної власності в Європейському Союзі.

Ці принципи є набором альтернативних доктринальних правил регулювання конфліктів інтелектуальної власності в Європейському Союзі, які мають на меті уніфікувати колізію законів, що стосуються конкретних відносин інтелектуальної власності, з метою усунення регуляторних прогалин та неефективних підходів у реґламентах Європейського Союзу в цій галузі.

Правила регламентів Європейського Союзу, які містять колізійні норми у спорах щодо інтелектуальної власності в наукових колах, піддаються критиці. Підстави для цієї критики в узагальненому розумінні зводяться до неефективності та непрактичності підходів, визначених регламентами щодо вибору закону, який застосовуватиметься, та встановлення юрисдикції у спорах щодо інтелектуальної власності, зважаючи на особливий статус, специфіку інтелектуальної власності; відсутність законодавчих норм для вирішення зазначених спорів щодо Інтернету.

Зокрема, положення «Принципів конфлікту законів у сфері інтелектуальної власності» передбачають можливість відхилення від необхідності та доцільності залежно від обставин справи, відхилення від суворого дотримання принципу "lex loci protectionis", застосування принципу "lex voluntatis" навіть у позадоговірних зобов'язаннях щодо інтелектуальної власності, також регулювались питання щодо численних відповідачів та певних правил юрисдикції у спорах щодо інтелектуальної власності, пов'язаних з Інтернетом та засобами масової інформації. 
«Принципи конфлікту законів у сфері інтелектуальної власності», як передбачається, мають високі шанси вплинути на майбутній розвиток міжнародного європейського приватного права, що змінить наявну правову базу Свропейського Союзу.

Ми вважаємо, що «Принципи конфлікту законів у сфері інтелектуальної власності» можна розглядати як джерело для створення нового необхідного законодавства на рівні Європейського Союзу про колізійне регулювання відносин інтелектуальної власності.

Оскільки «Принципи конфлікту законів у сфері інтелектуальної власності» містять важливі положення, які усувають прогалини в законодавстві Європейського Союзу в цій галузі, наприклад, щодо безлічі відповідачів у спорах щодо інтелектуальної власності, уперше намагаються забезпечити юридичне врегулювання конфліктів щодо спорів, пов'язаних з інтелектуальною власністю в Інтернеті.

Ключові слова: колізійні норми, принципи CLIP, Європейський Союз, спори з інтелектуальної власності.

\section{Summary}

Lukan M. O. The essence of the principles of conflict of laws in intellectual property. - Article.

In this article, the author reveals the structure and content of the "Principles of Conflict of Laws in Intellectual Property" (hereinafter - CLIP Principles) and their importance in regulating conflict intellectual property relations in the European Union.

These principles are a set of alternative doctrinal rules for conflict regulation of intellectual property in the European Union, which aim to unify the conflict of laws relating to specific intellectual property relations, in order to address regulatory gaps and ineffective approaches in European Union regulations in this area.

The rules of the European Union Regulations, which contain conflict-of-law rules in intellectual property disputes in scientific circles, are criticized. The grounds for this criticism in a generalized sense are reduced to the inefficiency and impracticality of the approaches defined by the Regulation in choosing the law to be applied and establishing jurisdiction in IP disputes, given the special status, "specificity" of intellectual property; lack of legal regulations for resolving IP disputes on the Internet.

In particular, the provisions of the CLIP Principles provide for the possibility to depart from necessity and expediency, depending on the circumstances of the case, to deviate from strict adherence to the principle of "lex loci protectionis", application of the principle of "lex voluntatis" even in non-contractual intellectual property obligations, the issue of multiple defendants and certain rules of jurisdiction in intellectual property disputes related to the Internet and the media also regulated.

These Principles are projected to have a high chance of influencing the future development of European private international law, which will change the existing European Union legal framework.

We believe that the CLIP Principles can be seen as a source for creating a new necessary piece of legislation at European Union level on conflict-of-law regulation of intellectual property relations.

Because the CLIP Principles contain important provisions that address gaps in European Union law in this area, for example, concerning the multiplicity of defendants in IP disputes and, for the first time, attempt to provide legal settlement of conflicts concerning IP disputes on the Internet.

Key words: conflict of laws rules, CLIP principles, European Union, IP-disputes. 